\title{
ISU PEKERJA ANAK DAN HUBUNGAN DENGAN HAK ASASI MANUSIA
}

\author{
Siti Faridah \\ Universitas Negeri Semarang \\ Semarang, Indonesia \\ J. Kampus Timur, Sekaran, Gunungpati, \\ Kota Semarang, Jawa Tengah 50229 \\ Surel: sfaridah99@gmail.com
}

\author{
Laila Afiyani \\ Universitas Negeri Semarang \\ Semarang, Indonesia \\ J. Kampus Timur, Sekaran, Gunungpati, \\ Kota Semarang, Jawa Tengah 50229 \\ Surel: afiyanilaila@gmail.com
}

\begin{abstract}
ABSTRAK
Terdiri Seiring waktu, eksploitasi pekerja anak di Indonesia meningkat setiap tahun. Hal ini disebabkan rendah ekonomi dan pendidikan yang kekuatan anakanak untuk bekerja dan membantu orang tua mereka secara finansial. Yuridis, Indonesia memiliki peraturan yang mengatur pekerja anak yang tercantum dalam undang-undang ketenagakerjaan. Hal ini dimaksudkan agar hak-hak anak-anak tidak diabaikan tapi masih dilindungi oleh pemerintah. Namun, aturan yang ada dari waktu ke waktu tidak sesuai dengan kompleksitas masyarakat yang terus berkembang sampai sekarang. Sehingga seolah-olah aturan yang berlaku tidak memiliki kekuatan untuk mengatur tatanan masyarakat. Menurut Konvensi Hak Anak, anak-anak memiliki hak untuk dilindungi dari segala bentuk eksploitasi ekonomi dan dari segala bentuk pekerjaan berbahaya dan mengganggu pendidikan, kesehatan, fisik, mental, spiritual, aspek moral dan sosial anak. Dalam hal ini, ada tiga pendekatan untuk melihat masalah pekerja anak, yaitu penghapusan, perlindungan, dan pemberdayaan.
\end{abstract}

\section{RIWAYAT ARTIKEL}

Article History

Diterima : 5 September 2019

Dipublikasi : 25 November 2019

\section{KATA KUNCI}

Keywords

Anak-anak, Pendidikan, Eksploitasi, Kemiskinan, Pekerjaan

\section{HOW TO CITE (saran perujukan):}

Faridah, Siti \& Afiyani, Laila (2019). "Isu Pekerja Anak Dan Hubungan Dengan Hak Asasi Manusia". Lex Scientia Law Review. Volume 2 No. 2, November. hlm. 163176. 


\section{PENDAHULUAN}

Anak-anak adalah aset berharga yang tak ternilai harganya. Bahkan Sri Purnianti dan Martini berpendapat bahwa anak-anak dapat memiliki hukum sosial, budaya, politik, ekonomi dan signifikansi sebagai subyek yang telah mampu mengambil tanggung jawab untuk diri mereka sendiri (Martini, 2002). Dalam hal ini, masalah timbul ketika anak-anak dieksploitasi dan digunakan sehingga hak-hak mereka dilanggar sebagai seorang anak. Bahkan, anak-anak harus mendapatkan perlindungan hukum yang telah ditentukan melalui UU. Perlindungan anak sesuai dengan Pasal 1 ayat (2) UU No. 23 Tahun 2002 adalah "semua kegiatan untuk jaminan dan anak-anak melindungi dan hak-hak mereka sehingga mereka dapat hidup, tumbuh, berkembang, dan berpartisipasi secara optimal sesuai dengan harkat dan kemanusiaan, sehingga mereka dilindungi dari kekerasan dan diskriminasi". Secara hukum, Indonesia sudah memiliki undang-undang yang hak jaminan anak-anak dan mengurangi dampak dari eksploitasi anak dari pekerjaan termasuk UUD 1945, ratifikasi Konvensi ILO nomor 138 dalam Undang-Undang Nomor 20 Tahun 1999 tentang. Usia minimum atau Izin untuk Kerja, ratifikasi Konvensi ILO (Setiamandani, 2012).

Hak-hak anak adalah hak asasi manusia yang harus dilindungi dan dihormati sebagaimana tercantum dalam UUD 1945 Bab XA terutama Pasal 28B ayat (2) di mana "setiap anak memiliki hak untuk hidup, pertumbuhan dan perkembangan dan berhak atas perlindungan dari kekerasan dan diskriminasi". Hak asasi manusia anak-anak juga ditegaskan dalam ketentuan Pasal 52 ayat (2) UU No. 39 Tahun 1999 tentang Hak Asasi Manusia, yaitu "Hak-hak anak adalah hak asasi manusia dan untuk kepentingan mereka hak-hak anak diakui dan dilindungi oleh hukum bahkan dari rahim". Berdasarkan Undang-Undang Nomor 20 Tahun 1999 tentang Pengesahan 1LO Konvensi No. 138 Mengenai Usia Minimum untuk Diperbolehkan Bekerja atau Konvensi ILO No. 138 Tahun 1973 Tentang Usia Minimum untuk Bekerja Izin, ketentuan 15 tahun.

Faktor-faktor yang menyebabkan munculnya tingkat pekerja anak didominasi oleh faktor kemiskinan. Selain itu, beberapa pekerja anak juga timbul dari konflik dan bencana yang ada di negara ini. Mempekerjakan anak secara tidak langsung akan membahayakan pertumbuhan perkembangan fisik, psikologis, mental, spiritual, moral, sosial dan intelektual dan anak. Sehingga langkah yang tepat untuk mengatasi masalah ini adalah melalui pendidikan. Pendidikan adalah kunci untuk menghilangkan pekerja anak dan untuk pengembangan masyarakat yang sejahtera.

\section{Rumusan Masalah}

1. Bagaimana kajian Hak Asasi Manusia dalam perspektif hukum positif?

2. Bagaimana kajian Hak Asasi Manusia dalam perspektif hukum progresif? 


\section{Metode Penulisan}

1. Pengumpulan Data

Metode Studi pustaka, dimana pengumpulan informasi yang dibutuhkan dilakukan dengan mencari referensi-referensi yang berhubungan dengan penelitian yang dilakukan, referensi dapat diperoleh dari buku-buku, jurnaljurnal atau internet.

2. Sumber Data

Sumber Data Sekunder, diperoleh dari buku-buku literatur dan jurnal ilmiah.

\section{PEMBAHASAN}

\section{Apa yang terjadi dengan Buruh di Indonesia?}

Dalam era globalisasi, proses kegiatan ekonomi dan perdagangan antara negara-negara di seluruh dunia menjadi sebuah kekuatan pasar yang semakin terintegrasi tanpa hambatan untuk batas teritorial negara. Dengan globalisasi, batas-batas ekonomi menjadi semakin kabur dan sempit. Sementara globalisasi dalam bentuk TTA, WTO, NAFTA dan lain-lain, akan lebih intensif. Di mana Indonesia akan menjadi pasar potensial bagi negara-negara ASEAN. Mengingat posisi negara strategis, Indonesia dengan jumlah penduduk yang besar dan tingkat tinggi konsumsi. Ini akan menjadi kesempatan dan tantangan bagi pengembangan kerja (Soleh, 2001).

Konsep kerja itu sendiri didefinisikan sebagai penduduk usia yang siap untuk melakukan pekerjaan, yaitu usia 15-65 tahun bekerja. Menurut undangundang Tenaga Kerja, tenaga kerja "siapa saja yang mampu melakukan pekerjaan untuk barang dan jasa produksi, baik untuk memenuhi kebutuhan mereka sendiri serta orang lain atau masyarakat". Berdasarkan data dari Badan Pusat Statistik Republik Indonesia menjelaskan bahwa Indonesia akan mengalami bonus demografi dalam beberapa tahun ke depan, puncak yang akan di tahun 2025. Dimana pada tahun itu usia tenaga kerja akan berlimpah, dan kemauan ini menjadi tantangan. Selain itu, jumlah angkatan kerja terus meningkat setiap tahun (www.bps.go.id). Bila dilihat dari perspektif yang berbeda, tenaga kerja merupakan salah satu sumber daya yang paling penting dalam mendorong pertumbuhan dan kemajuan ekonomi suatu negara. Namun, hal yang salah terjadi ketika status seorang anak dieksploitasi dan dipekerjakan yang melanggar hak asasi manusia sebagai seorang anak.

Dilihat melalui permintaan tenaga kerja di Indonesia, pasar tenaga kerja Indonesia mengalami perkembangan yang cukup baik. Hal ini dibuktikan dengan peningkatan jumlah pekerjaan dan penurunan angka pengangguran terbuka pada waktu yang sama seperti pertumbuhan penduduk yang cukup tinggi. Masalah pengangguran dan lapangan kerja masih menjadi perhatian utama di setiap negara di dunia, terutama di negara-negara berkembang. Selain menjadi beban dan hambatan dalam pertumbuhan ekonomi suatu negara adalah, pengangguran juga 
merupakan indikator pasar tenaga kerja yang ada.

Masalah Utama Dalam Angkatan Kerja Di Indonesia: Ekonomi Rendah Dan Tenaga Kerja Anak

Tahun 2018 telah berlalu dengan mudah. Banyak masalah ekonomi mulai dari penurunan kurs rupiah tukar, masalah fiskal, pendapatan negara rendah dari ekspor, perang perdagangan antara Amerika dan Cina, serta kekacauan politikpopulis yang ikut menjadi batu sandungan yang signifikan. Masalah kronis yang dialami Indonesia sebelumnya sejak orde baru adalah tingkat produktivitas (ekspor barang dengan nilai tambah) yang sangat rendah. Ketergantungan kemudian pada bahan bakar minyak impor. Kedua masalah akan terus menghantui nilai gerakan Rupiah, inflasi dan kesehatan negara keuangan. Kurangnya penerimaan negara dari sektor pajak, yang disebabkan oleh rendahnya nilai ekspor akan terus merongrong keuangan negara.

Sementara itu, untuk meningkatkan produktivitas didasarkan pada teknologi terapan, sumber daya manusia yang berkualitas tinggi diperlukan. Bila dilihat dari kondisi pengembangan sumber daya manusia dari tingkat indeks daya saing pada tahun 2018, Indonesia berada di posisi ke-45 jauh di belakang negaranegara tetangga terdekat seperti Thailand, Malaysia, dan Singapura, meskipun dalam sepuluh tahun Indonesia telah meningkat 10 angka dari 55 ke posisi 45 (www.kompasiana.com). Pembangunan ekonomi di Indonesia saat ini dihadapkan dengan masalah kemiskinan. Umumnya, di negara-negara berkembang seperti Indonesia, masalah penerbangan pendapatan dan kemiskinan merupakan masalah utama di bidang ekonomi pembangunan.

Kemiskinan merupakan masalah klasik yang sulit untuk memecahkan, berarti kemiskinan adalah masalah yang dihadapi dan perhatian di setiap negara. Masalah kemiskinan merupakan salah satu masalah utama yang dihadapi oleh bangsa Indonesia sejak zaman kuno sampai sekarang. Berbagai perencanaan, kebijakan dan program pembangunan yang telah dan akan dilaksanakan pada intinya mengurangi jumlah orang miskin. Masalah kemiskinan adalah masalah yang kompleks dan multidimensi. Upaya pengentasan kemiskinan harus dilakukan secara komprehensif, mencakup semua aspek kehidupan dan dilakukan secara terpadu. Kemiskinan terjadi karena kemampuan pelaku ekonomi masyarakat tidak sama, sehingga ada orang yang tidak dapat berpartisipasi dalam proses mengembangkan mentor menikmati hasil pembangunan (Soegijoko, 2001).

Perhatian pemerintah Indonesia terhadap kemiskinan diuraikan dalam Pembangunan Nasional Jangka Menengah Rencana 2015-2019. Penurunan kemiskinan untuk 10,86 persen pada tahun 2016 adalah salah satu target pertama dalam hal agenda pemerintah untuk meningkatkan kesejahteraan rakyat. Untuk mencapai target tersebut, pemerintah merumuskan 2015-2019 prioritas pembangunan nasional, yaitu pengentasan kemiskinan dengan kebijakan yang ditujukan untuk menghormati, melindungi, dan memenuhi hak-hak dasar miskin 
(Frederic W Kiha, 2018).

Faktor-faktor yang menyebabkan kemiskinan meliputi; rendahnya tingkat pendidikan, rendahnya tingkat kesehatan, lapangan kerja yang terbatas, dan kondisi isolasi (Kartasamita, 1996). Dalam laporan yang dirilis dari Bank Dunia, ada 5 faktor yang dianggap mempengaruhi terjadinya kemiskinan, yaitu: pendidikan, jenis pekerjaan, jenis kelamin, akses ke layanan kesehatan dasar dan infrastruktur dan lokasi geografis (Suahasil Nazara, 2007). Kemiskinan sering ditandai oleh tingginya tingkat pengangguran dan keterbelakangan. Masyarakat miskin umumnya lemah dalam kemampuan mereka untuk melakukan bisnis dan memiliki akses ke kegiatan ekonomi sehingga mereka akan tertinggal jauh dari masyarakat lain yang memiliki potensi tinggi terbatas. Ukuran kemiskinan dalam hal tingkat pendapatan dapat dikelompokkan ke dalam kemiskinan absolut dan kemiskinan relatif (Suahasil Nazara, 2007). Seseorang dikatakan benar-benar miskin jika penghasilannya lebih rendah dari garis kemiskinan absolut atau dalam istilah lain, penghasilannya tidak cukup untuk memenuhi kebutuhan minimum hidup.

Jika kita menggunakan nilai garis kemiskinan yang digunakan oleh Bank Dunia, yang mengklasifikasikan persentase Indonesia gaji kurang dari USD \$ 1,25 per hari seperti yang hidup di bawah garis kemiskinan. Selain itu, menurut Bank Dunia, jumlah penduduk Indonesia yang hidup dengan kurang dari USD \$ 2 per hari akan meningkat bahkan lebih tajam. Laporan terbaru bahkan menginformasikan bahwa sekitar seperempat dari penduduk Indonesia ( \pm 65 juta orang) hidup hanya sedikit di atas garis kemiskinan nasional (www.indonesiainvestments.com).

Salah satu karakteristik kemiskinan di Indonesia adalah perbedaan besar antara nilai kemiskinan relatif dan nilai kemiskinan absolut dalam kaitannya dengan lokasi geografis. Jika secara mutlak lebih dari setengah dari total penduduk Indonesia hidup dalam kemiskinan adalah di pulau Jawa (yang terletak di bagian barat Indonesia dengan populasi padat), dalam arti relatif provinsi di Indonesia Timur menunjukkan sebuah nilai kemiskinan yang lebih tinggi. Menurut data dari Badan Pusat Statistik Maret 2019, jumlah orang miskin 25.140.000. Angka ini turun 810.000 penduduk dibandingkan dengan periode yang sama tahun sebelumnya. Bila dilihat dari persentase penduduk, penduduk miskin hingga Maret 2019 adalah 9,41 persen atau menurun dibandingkan dengan 9,82 persen tahun sebelumnya (www.m.cnnindonesia.com).

Perkembangan ekonomi Indonesia di mata dunia saat ini memang lebih baik bila dibandingkan dengan beberapa tahun yang lalu. Hal ini dapat dibuktikan dengan daya beli meningkat dari barang-barang tertentu dan meningkatkan pendapatan per kapita meskipun masih dalam skala kecil. Namun, dapat dilihat bahwa tidak semua hal telah meningkat, masih ada beberapa hal yang memiliki hubungan dengan perekonomian Indonesia yang mengalami penurunan. Hal ini dianggap wajar karena pertumbuhan ekonomi tidak bisa hanya dilihat dari satu daerah tetapi dapat dilihat dari berbagai bidang. Selain itu, beberapa aspek lain atau 
bidang juga memberikan kontribusi terhadap masalah pembangunan ekonomi Indonesia, seperti aspek sosial-politik, aspek keamanan negara dan berbagai aspek lainnya.

\section{Masalah Pekerja Anak di Indonesia}

Secara garis besar, penduduk suatu negara dibagi menjadi dua kelompok, yaitu tenaga kerja dan bukan tenaga kerja. Populasi diklasifikasikan sebagai tenaga kerja jika penduduk telah memasuki usia kerja. Batas usia kerja yang berlaku di Indonesia adalah 15 tahun - 64 tahun. Sementara penduduk berusia kurang dari 15 tahun dan lebih dari 64 tahun, mereka tidak milik kelompok tenaga kerja (Badan Pusat Statistik Kabupaten Jepara).

Anak-anak adalah aset tak ternilai harganya, tidak hanya dari budaya perspektif sosial, ekonomi, politik dan hukum, tetapi juga dalam perspektif keberlanjutan generasi keluarga, suku, ras, dan bangsa. Mengingat pentingnya status dan posisi anak, anak dapat secara sosial bermakna (kehormatan, martabat, harga diri keluarga tergantung pada sikap dan perilaku anak), budaya (anak adalah harta dan kekayaan serta simbol kesuburan seorang keluarga), politik (anak adalah penerus generasi atau suku masyarakat tertentu), ekonomi (pada saat ini anggapan masyarakat Jawa khususnya ada pepatah "banyak anak, banyak rezeki", sehingga " mempunyai" atau mempekerjakan anak-anak dengan jumlah banyak dapat menambah penghasilan atau keberuntungan) (Setiamandani, Perlindungan Hukum untuk Pekerja Anak dan Mitigasi mereka Upaya, 2012).

Salah satu masalah anak-anak yang membutuhkan perhatian khusus adalah masalah pekerja anak. Masalah ini telah menjadi masalah global karena begitu banyak anak-anak di seluruh dunia yang sudah bekerja di usia sekolah. Bahkan, isu pekerja anak bukan hanya masalah anak-anak melaksanakan pekerjaan untuk hidup, tapi terhubung sangat erat dengan eksploitasi, pekerjaan yang berbahaya, akses terhambat pembangunan fisik, psikologis dan sosial pendidikan dan menghambat anak-anak. Bahkan dalam kasus dan bentuk pekerja anak tertentu, telah memasuki kualifikasi anak yang bekerja dalam bentuk yang paling tak tertahankan dari pekerja anak dan melanggar hak-hak anak. (Prajnaparamita, 2018).

Meskipun ada seperangkat peraturan yang pekerja anak melindungi, kecenderungan kualitas masalah pekerja anak dari tahun ke tahun mengalami perkembangan kompleksitas terhadap bentuk-bentuk terburuk pekerjaan eksploitatif bahwa pertumbuhan Membahayakan dan intelektual fisik, mental, moral, sosial dan perkembangan anak-anak. Jenis terburuk pekerjaan semakin ditemukan, seperti anak-prostitusi, anak-perdagangan, dan lain-lain(Wiryani, 2003). Semua yang tersisa karena kita menyadari.

Menurut Konvensi PBB tahun 1989 tentang Hak Anak dan Konvensi ILO Nomor 182 Tahun 1999 tentang Larangan dan Segera Penghapusan Tindakan Bentuk-bentuk Terburuk Pekerja Anak, anak di bawah 18 tahun. Definisi Pekerja 
Anak menurut ILO / IPEC adalah anak-anak yang bekerja di semua jenis pekerjaan yang membahayakan atau mengganggu secara fisik, mental, intelektual dan moral. Konsep pekerja anak didasarkan pada Konvensi ILO No. 138 tentang usia minimum untuk diperbolehkan bekerja yang menggambarkan definisi internasional yang paling komprehensif dari usia minimum untuk diperbolehkan bekerja, mengacu langsung ke "aktivitas ekonomi". Konvensi ILO menentukan rentang usia minimum di bawah mana anak-anak tidak diperbolehkan bekerja. Minimum usia sesuai dengan Konvensi ILO No. 138 untuk negara-negara di mana perekonomian dan fasilitas pendidikan kurang berkembang adalah anak-anak berusia 5-11 tahun yang melaksanakan kegiatan ekonomi pekerja anak sehingga perlu dihapuskan. Anak-anak 12 - 14 tahun yang bekerja dianggap pekerja anak, kecuali jika mereka melakukan pekerjaan ringan. Sementara sampai dengan usia 18 tahun tidak diizinkan untuk bekerja di pekerjaan yang dianggap berbahaya (Konvensi PBB).

Internasional sejak tahun 1989, masyarakat dunia telah memiliki instrumen hukum, yaitu Konvensi Hak Anak (KHA), yang memiliki kekuatan untuk mengikat negara-negara peserta dan menandatangani KHA. KHA menjelaskan hak-hak anak secara rinci, menyeluruh dan forwardly. Posisi KHA anak-anak sebagai diri mereka sendiri dan hak-hak anak sebagai segmen (bagian) dari manusia yang harus diperangi bersama orang dewasa. KHA yang memiliki 54 artikel dapat dikategorikan menjadi empat hak, yaitu: hak perlindungan, hak kelangsungan hidup, hak pengembangan dan hak partisipasi.

Sebagai negara yang telah meratifikasi Konvensi Hak Anak (KHA) dalam Keputusan Presiden No.36 tahun 1990, yang kemudian mengeluarkan UU No. 10 tahun 2012 tentang Pengesahan Protokol Konvensi Opsional tentang Hak-hak Anak. Jadi baik itu kita mengacu pada KHA untuk semua masalah di sekitar anakanak kita bertemu. Dalam pasal $32 \mathrm{KHA}$, dinyatakan bahwa anak-anak memiliki hak untuk dilindungi dari segala bentuk eksploitasi ekonomi dan dari segala bentuk pekerjaan yang bentuk berbahaya dan mengganggu pendidikan mereka, membahayakan kesehatan mereka atau mengganggu pekerja anak adalah perkembangan fisik, mental, spiritual, moral dan sosial anak. Oleh karena itu negara berkewajiban untuk menetapkan batas usia minimum untuk pekerja anak, aturan waktu dan kondisi penempatan kerja (hukumonline.com).

Masalah pekerja anak atau pekerja anak diatur dalam pasal 68 sampai pasal 75 hukum perburuhan, yang juga menetapkan bahwa batas usia untuk anak-anak yang diperbolehkan untuk bekerja adalah 15 tahun, baik untuk anak laki-laki dan untuk anak perempuan. Kemudian, melalui Konvensi ILO No. 182 Tahun 1999 tentang Larangan dan Tindakan Segera Penghapusan Bentuk-bentuk Pekerjaan Terburuk untuk Anak, disahkan dengan Undang-Undang Nomor 01 Tahun 2000. Sebagai tindak lanjut untuk ratifikasi, Komite Aksi Nasional ( KAN) untuk Penghapusan bentuk-bentuk Pekerjaan terburuk untuk anak dibentuk melalui Keputusan Presiden Nomor 12 tahun 2001. KAN kemudian membentuk Rencana Aksi Nasional (RAN) yang bertujuan untuk mencegah dan menghilangkan anak- 
anak dari terlibat dalam semua jenis bentuk-bentuk terburuk pekerja anak.

Tapi menanggapi pertanyaan apakah regulasi memadai dan sejauh mana pelaksanaannya masih jauh dari mudah karena hingga kini masalah pekerja anak masih kontroversial dalam isu perlindungan anak pada umumnya. Bisa dikatakan, masalah pekerja anak merupakan masalah klasik dalam hal perlindungan anak. Seperti yang akan terungkap sebelumnya, anak-anak di Indonesia sebenarnya dilindungi oleh hukum. Tantangannya tampaknya dalam penegakan hukum karena hingga saat ini di Indonesia masih cukup banyak anak-anak yang bekerja dan sama sekali tidak ada jaminan bahwa mereka semua akan benar dilindungi. Anak-anak memiliki risiko tinggi menjadi korban berbagai bentuk pelecehan atau bahkan dibunuh.

Dalam tulisan ini merujuk pada anak-anak berusia 5-17 tahun. Batas usia ini sejalan dengan standar ILO dan juga dengan peraturan yang relevan sesuai dengan ketentuan Departemen Tenaga Kerja dan Transmigrasi Pemerintah Indonesia. Di Indonesia, dan mungkin di negara-negara lain juga, anak-anak dalam kelompok usia tertentu dianggap sebagai penduduk usia sekolah dan diharapkan akan masih terdaftar di sekolah, apakah pra-sekolah, sekolah dasar atau sekolah tinggi. Namun, dalam kenyataannya, tidak selalu seperti yang diharapkan.

Dalam undang-undang tentang perlindungan anak, dinyatakan bahwa salah satu langkah perlindungan khusus bagi anak-anak adalah perlindungan bagi anakanak yang dieksploitasi secara ekonomi. Upaya pemerintah untuk memberikan perlindungan bagi anak-anak yang dieksploitasi secara ekonomi, salah satunya adalah dengan memberikan perlindungan kepada pekerja anak dalam bentuk yang melibatkan berbagai perusahaan, serikat pekerja, organisasi non-pemerintah, dan masyarakat dalam menghilangkan eksploitasi ekonomi terhadap anak. Masalah pekerja anak juga berkaitan erat dengan kemiskinan dan keterbelakangan. Sebagian besar anak-anak bekerja karena mereka berasal dari keluarga miskin / keluarga miskin.

Menurut UU No 23 Tahun 2002 pasal 1 menyatakan bahwa "Perlindungan anak adalah segala kegiatan untuk menjamin dan anak-anak melindungi dan hakhak mereka sehingga mereka dapat hidup, tumbuh dan berkembang dan berpartisipasi secara optimal sesuai dengan harkat martabat manusia, serta mendapatkan perlindungan dari diskriminasi kekerasan, eksploitasi ekonomi yang baik. serta seksual, penelantaran, kekejaman, kekerasan dan penganiayaan, ketidakadilan, penganiayaan lainnya.(Sulastri, 2016)

Undang-Undang Nomor 13 Tahun 2003 tentang hukum perburuhan dalam pasal 68 menyebutkan bahwa pengusaha dilarang mempekerjakan anak. Ketentuan pasal 68 dikecualikan untuk anak usia 13-15 untuk melakukan pekerjaan ringan sepanjang tidak mengganggu perkembangan dan kesehatan fisik, mental dan sosial. Undang-undang ini juga menetapkan bahwa pengusaha yang anak mempekerjakan di pekerjaan ringan harus memenuhi persyaratan, yaitu, izin tertulis dari orang tua atau wali, perjanjian kerja antara pengusaha dan orang tua atau wali, waktu kerja 
maksimum adalah 3 jam, dilakukan pada siang hari dan tidak mengganggu waktu sekolah, keselamatan dan kesehatan kerja, hubungan kerja yang jelas dan anak menerima upah sesuai dengan ketentuan yang berlaku. Namun, meskipun sudah ada undang-undang yang melarang anak-anak bekerja di semua sektor ekonomi, (Sulastri, 2016).

Menurut undang-undang tenaga kerja, anak-anak dalam kelompok usia 1012 tahun sebenarnya tidak diperbolehkan untuk bekerja (bahkan untuk pekerjaan ringan). Hanya anak-anak di atas usia 13 diizinkan untuk melakukan pekerjaan ringan. Namun, sesuai dengan Konvensi ILO No.138 yang telah diratifikasi menjadi UU No.20 Tahun 1999 tentang usia minimum untuk bekerja, anak-anak berusia 15 tahun dapat digunakan secara normal sehingga kelompok usia 13-17 tahun dibagi menjadi dua, yaitu 13-14 tahun dan 15-17 tahun. Anak-anak dalam kelompok usia 15-17 tahun diperbolehkan bekerja tetapi tidak dapat dimanfaatkan untuk bekerja di pekerjaan yang membahayakan baik bahaya bagi kesehatan atau keselamatan atau moral anak (Body, 2018). Konteks dimaksud dalam undangundang perlindungan anak adalah suatu bentuk perlindungan yang diterima oleh lembaga-lembaga anak-anak tertentu dan kondisi untuk mendapatkan rasa aman terhadap ancaman yang membahayakan diri mereka sendiri dan kehidupan dalam pertumbuhan dan perkembangan mereka. Setiap anak berhak untuk mendapatkan perlindungan dari: penyalahgunaan dalam kegiatan politik, dimasukkan dalam sengketa bersenjata, dimasukkan dalam kerusuhan sosial, dimasukkan dalam insiden yang mengandung unsur kekerasan, dimasukkan dalam perang, dan kejahatan seksual.

\section{Dampak Adanya Pekerja Anak}

Risiko seperti pemerkosaan, pembunuhan, pemaksaan, kelalaian, perdagangan, prostitusi, dan perilaku yang tidak benar adalah contoh konkret yang harus wajah anak karena ketidakberdayaan untuk menghindari risiko ini (Endrawati, 2012). Maraknya pekerja anak di Indonesia semakin menjamur. Berbagai alasan untuk mengoreksi lagi muncul untuk dapat melegalkan tindakan ini. Kontribusi anak-anak di lingkaran peredaran uang adalah masalah yang terpisah di berbagai belahan dunia karena, pada dasarnya, ini telah menjadi masalah bagi setiap negara. Munculnya pekerja anak tidak terlepas dari berbagai faktor yang berkontribusi di balik itu, berikut ini menjelaskan faktor munculnya pekerja anak, termasuk:

1. Faktor-faktor ekonomi

Kemiskinan adalah salah satu penyebab utama munculnya pekerja anak di samping faktor ekonomi lainnya. Ketidakmampuan ekonomi keluarga memiliki efek pada produktivitas kerja yang rendah, kurang gizi, kurang perawatan kesehatan sehingga hasil ini dalam kapasitas berkurang pekerjaan, kelelahan, kerentanan terhadap kecelakaan dan penyakit. pendapatan orangtua rendah, menyebabkan anak-anak dipaksa untuk mengikuti jejak orang tua mereka bekerja bahkan tanpa pemberian keterampilan. 
2. Faktor budaya

Budaya dalam keluarga yang anak-anak dari usia muda memiliki pekerjaan dilakukan atau sebagai pekerja. Tanpa disadari, orang tua menganggap kerja sebagai pekerja anak adalah tradisi di komunitas mereka. Anak-anak diperintahkan untuk bekerja sebagai pekerja dengan alasan mendapatkan pendidikan terbaik dan persiapan untuk menghadapi hidup di masyarakat kemudian ketika anak adalah orang dewasa. Tanpa disadari keberadaan budaya atau tradisi, kebiasaan ini memberikan anak-anak mereka sebagai pekerja anak (usia mereka) yang seharusnya tidak punya waktu untuk bekerja.

3. Faktor pendidikan

Mulai dari pendidikan orang tua yang rendah, tradisi ekonomi dan keterbatasan, banyak orang tua mengambil jalan pintas agar anak-anak mereka putus sekolah dan bekerja lebih baik untuk alasan:

a) Wanita tidak perlu sekolah tinggi

b) biaya pendidikan tinggi

c) Sekolah tinggi akhirnya menjadi pengangguran

4. Rendahnya tingkat pendidikan dan ketidakberdayaan ekonomi, orang tua cenderung berpikiran sempit menuju masa depan anak-anak mereka sehingga mereka tidak memperhitungkan manfaat dari sekolah yang lebih tinggi dapat meningkatkan kesejahteraan anak-anak di masa depan. Situasi ini apa drive anak-anak untuk memilih menjadi pekerja anak.

Mempekerjakan pekerja anak pada dasarnya adalah pelanggaran hak anak karena pekerja anak mempengaruhi selalu buruk terhadap perkembangan fisik, emosional dan sosial anak. Keberadaan pekerja anak dapat memiliki efek sendiri. Dampak Eksploitasi Pekerja Anak pekerja anak dapat menyebabkan berbagai gangguan pada anak-anak baik secara fisik dan mental.

Secara khusus, dampak dari anak yang bekerja di masing-masing sektor berbeda, seperti dampak dari anak yang bekerja di sektor pertambangan sangat berbeda dari dampak anak yang bekerja dalam penjualan, produksi dan perdagangan obat-obatan. Selain dampak khusus, pekerja anak juga memiliki dampak umum (Sulastri, 2016), yaitu:

a. Tidak memiliki waktu luang untuk bermain

b. Gangguan proses perkembangan anak

c. Gangguan kesehatan fisik dan mental anak-anak

d. Perasaan rendah diri dalam hubungan

e. Rentan terhadap perlakuan diskriminatif

f. Rentan terhadap kecelakaan kerja

g. Rentan terhadap perlakuan tindak kekerasan, eksploitasi dan pelecehan rentan menciptakan generasi miskin (pekerja anak yang melahirkan pekerja anak juga) 
h. Masa depan yang suram karena pendidikan rendah atau bahkan tidak ada pendidikan.

i. Tidak mampu bersaing dengan pihak lain di era globalisasi.

Selain dampak umum, pekerja anak juga memiliki dampak tertentu, yaitu: (Nandi, 2006)

a) Dampak dari bekerja pada perkembangan fisik anak.

Secara fisik pekerja anak lebih rentan daripada orang dewasa karena mereka masih secara fisik tumbuh. Bekerja sebagai pekerja anak dapat mempengaruhi perkembangan kesehatan fisik mereka karena pekerjaan yang mereka lakukan dapat menyebabkan kecelakaan atau penyakit.

b) Dampak dari pekerjaan pada perkembangan emosi anak

Pekerja anak sering bekerja di lingkungan kerja yang memungkinkan eksploitasi, berbahaya, merendahkan, merendahkan dan terisolasi. Mereka sering menerima pelecehan, kekerasan, dan penelantaran oleh pengusaha dan pekerja mereka dewasa lainnya. Dampaknya adalah dalam bentuk pekerja anak makhluk pemarah, pendendam, kasar terhadap teman sebaya atau lebih muda, kurang kasih sayang terhadap orang lain dan tidak merasa empati terhadap orang lain.

c) Dampak dari pekerjaan pada perkembangan sosial anak.

pekerja anak yang tidak memiliki kesempatan untuk melaksanakan kegiatan seperti bermain, pergi ke sekolah dan bersosialisasi dengan rekan-rekan mereka, tidak mendapatkan pendidikan dasar yang dibutuhkan untuk mengatasi masalah kehidupan, tidak memiliki kesempatan untuk berinteraksi dengan orang lain dan secara aktif berpartisipasi dalam masyarakat dan menikmati hidup secara alami biasanya akan tumbuh menjadi anak yang pasif dan egois sehingga sering dampak anak mengalami masalah dalam berinteraksi dengan orang lain dan mereka kurang percaya diri.

d) Sebagaimana dijelaskan bahwa anak-anak sebagai potensi dan generasi muda wajib untuk melanjutkan cita-cita perjuangan bangsa dan menjamin keberadaan bangsa di masa depan. Untuk mewujudkan tujuan ini merupakan kewajiban dan tugas dari generasi sebelumnya untuk memberikan arahan, bimbingan dan memberikan kesempatan seluas mungkin bagi anak-anak untuk maju dan berkembang dan berusaha untuk pencegahan dan penghapusan pekerja anak di Indonesia secara bertahap.

\section{Hubungan antara Pekerja Anak dan Hak Asasi Manusia}

Salah satu masalah anak-anak yang harus mendapat perhatian khusus adalah pekerja anak (Prajnaparamita, "Perlindungan Pekerja Anak", 2018). Berdasarkan data dari Badan Pusat Statistik Republik Indonesia pada 2017, ada 1,5 persen dari pekerja anak di Indonesia. Jumlah ini setara dengan 1,2 juta anak di seluruh Indonesia. Data berikut ini didasarkan pada tenaga kerja bidang anak dalam bisnis rentan 10-17 tahun. 


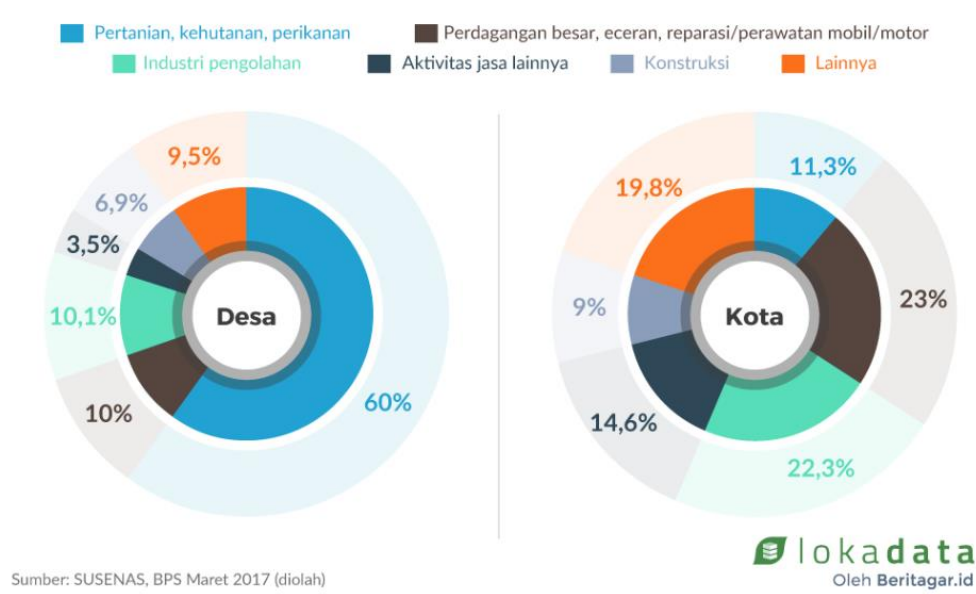

Berdasarkan 1989 PBB Hak Anak Konvensi, ada 10 hak yang harus diberikan kepada anak-anak. Di antara mereka yang Tepat untuk Play. Menghabiskan waktu untuk bekerja, membuat hak-hak anak dapat diabaikan (beritagar.id). Itumasalah pekerja anak berkaitan erat dengan hak asasi manusia yang tidak hanya nasional tetapi juga internasional. Masyarakat internasional telah memberikan perhatian serius terhadap masalah ini. Hal ini dibuktikan dengan realisasi perjanjian internasional yang dituangkan dalam berbagai konvensi termasuk Konvensi ILO No. 138 tahun 1973 dan Konvensi ILO No. 182 tahun 1999. Dukungan penuh dari konvensi ini telah diimplementasikan dalam bentuk peraturan nasional yang mengatur pekerja anak.

Filosofi melarang anak-anak dari bekerja sebagaimana diatur dalam hukum perburuhan sebenarnya terkait erat dengan upaya untuk melindungi hak-hak anak, yang juga dijamin perlindungan dalam UU Nomor 39 Tahun 1999 tentang Hak Asasi Manusia. Ketentuan yang melarang pekerja anak sebagaimana diatur dalam ketentuan pasal 68 undang-undang tenaga kerja, yang sejalan dengan ketentuan pasal 52 ayat (1) UU no. 39 Tahun 1999 tentang Hak Asasi Manusia, yang menentukan bahwa setiap anak berhak atas perlindungan oleh orang tua, keluarga, masyarakat, dan negara. Selanjutnya, ayat (2) mengatur hak-hak anak sebagai hak asasi manusia dan untuk kepentingan hak-hak anak diakui dan dilindungi oleh hukum bahkan dari rahim. Karena itu, (Endrawati, "Faktor Penyebab Anak untuk Bekerja dan Mencegah Upaya", 2011).

Perlindungan anak dari eksploitasi ekonomi yang mempekerjakan anakanak merupakan bagian dari perlindungan hak kelangsungan hidup. Pekerja anak merupakan bentuk pelanggaran hak-hak anak dan hambatan yang besar untuk pekerjaan yang layak berkelanjutan untuk pengembangan dan noda kemanusiaan. Memberantas mereka adalah apriori ekonomi global dan disepakati secara internasional. Melalui Sasaran 8,7 dalam Development Goals Berkelanjutan (SDGs), masyarakat dunia telah berkomitmen untuk menghilangkan semua bentuk pekerja anak pada tahun 2025. Target ini hanya dapat dicapai jika tidak ada anakanak yang ditinggalkan dalam memerangi pekerja anak - tidak peduli seberapa sulit dan menantang situasi. Untuk anak-anak, tidak yang sesuai untuk dipekerjakan. 


\section{KESIMPULAN}

Pekerja anak muncul dari latar belakang dari beberapa hal. Faktor utama adalah kemiskinan. Kemiskinan membuat seseorang tidak mampu memenuhi kebutuhannya sendiri atau dikatakan di bawah upah minimum. Hal yang dilakukan adalah melakukan berbagai cara untuk mengatasi permasalahan yang ada. Tindakan mayoritas diambil oleh miskin ini adalah untuk mempekerjakan anak-anak mereka meskipun secara hukum bertentangan dengan UU dan melanggar hak asasi manusia anak-anak yang secara jelas diatur dalam konvensi hak-hak anak. Bertujuan ini, masalah ini dapat diselesaikan melalui peningkatan kualitas pendidikan dan pemahaman perlindungan anak kepada masyarakat di mana status anak-anak memiliki aturan atau batasan sehingga mungkin tidak ada hak dieksploitasi dalam bentuk apapun.

\section{DAFTAR PUSTAKA}

Buku

Budhy T, Soegijoko, et al. 2001. "Manajemen Perkotaan di Menghadapi Tantangan Pembangunan Perkotaan". Bandung: Prosiding Forum Manajemen Perkotaan.

Kartasamita, Ginandjar. 1996. "Pembangunan untuk Rakyat; Mengintegrasikan Pertumbuhan dan Kesetaraan" Jakarta: CIDES

Kolaborasi antara Kementerian Pemberdayaan Perempuan dan Perlindungan Anak dengan pusat statistik. "Profil anak-anak Indonesia 2018" tahun 2018.. Jakarta: Kementerian Pemberdayaan Perempuan dan Perlindungan Anak ini.

Purnianti, Sri SM dan Martini. 2002. "Analisis dari Sistem Peradilan Anak". Jakarta: FISIP UI.

Wiryani, Fifik. 2003. "Perlindungan Pekerja Anak, Pusat Studi Kajian Wanita". Malang: UMM Press.

\section{Jurnal}

Endrawati, Netty. 2012. "Perlindungan Hukum Pekerja Anak di Sektor Informal", Journal of Legal Dynamics, Vol 12, No 2, hlm. 278.

Endrawati, Netty. "Faktor-faktor yang Menyebabkan Anak Kerja dan Pencegahan Upaya" . Scientific Hukum-Hukum refection Journal, Salatiga: UKSW Fakultas Hukum, hlm. 22.

Nalle, Frederic W dan Emilia K. Kiha. 2018. "Analisis Faktor-Faktor yang Mempengaruhi Tingkat Kemiskinan di Kecamatan Insana, Kabupaten Timor Tengah Utara (TTU)", Jurnal Ekonomi Pembangunan Dynamics JdeP Vol. 1 No. 3 hlm. 36.

Nandi. 2006. "Pekerja anak dan masalah nya", GEA jurnal jurusan geografi vol.6, 
no.2 Oktober, hlm.56.

Prajnaparamita, Kanyaka. 2018. "Perlindungan Pekerja Anak". Hukum Adminitrative \& Pemerintahan Journal Vol. 1 Edisi Khusus 1, hlm. 114.

Setiamandani, Emei Dwinanarhati. 2012. "Perlindungan Hukum untuk Pekerja Anak andEfforts Mitigasi". Reformasi Journal, Vol 2, No. 2, p. 74.

Soleh, Ahmad. 2016. "Kerja dan Pengangguran Masalah di Indonesia" .Scientific Cano Ekonomos Journal Vol. hal.86 6 No. 2 Jul.

Sulastri, Dewi. 2016. "Faktor-faktor Yang Disebabkan Eksploitasi Pekerja Anak di Kelian Dalam Desa Tambang Emas Tradisional di Tering Kabupaten". eJournal Sociatri- Sosiologi, Volume 4, Nomor 2 hlm. 254.

Majalah

Nazara, Suahasil.2007. "Pengangguran, Kemiskinan dan Pertumbuhan Ekonomi Indonesia". Pada tahun ke-37 Demografi Berita No 4. Jakarta: Lembaga Demografi Universitas Indonesia, hlm. 35.

Konvensi PBB tentang Hak Anak dan Konvensi ILO Nomor 182 Tahun 1999 tentang Larangan dan Tindakan Segera Penghapusan Bentuk-bentuk Pekerjaan Terburuk untuk Anak.

Suhardjo, AJ 1997. "Kemiskinan Stratifikasi dan Distribusi Pendapatan di Pedesaan (Kasus Tiga Hamlets di Coral Daerah Selatan, Gunung Merapi, Jawa Tengah)". Indonesia Majalah Geografi No. 19 th. 11, Maret, Fakultas Geografi, Universitas Gadjah Mada, Yogyakarta. hlm. 26.

Sumber Online

Adzkia, Aghina. 2018. "Pekerja anak di bawah kemiskinan dan kekurangan pendidikan". Diakses melalui https://beritagar.id/artikel/berita/perja-anak-di-bawahbayang- kemiskinan dan-minimal-pendidikan halaman pada 20 Juli 2019 di 14,33 WIB.

Badan Pusat Statistik. 2019. diakses melalui halaman https://www.bps.go.id/pressrelease/2019/05/06/1564/february-2019-pengangguran-tingkat-terbuka - TPT - sebesar -5-01 persen. Html pada 7 Agustus 2019 pukul 21.45 WIB.

Kusumaingrum, Santi. 2002. "tentang pekerja anak", diakses melalui pageaboutenergi-kerja-tenaga kerja-anak /https://www.hukumonline.com/klinik/detail/ulasan/c1918/ pada 5 Agustus 2019 di 20.09 WIB.

Reviyanto, Dhemas. 2019. "Masalah Perekonomian Indonesia tahun 2019", diakes melalui pagechallenge yanghttps://www.kompasiana.com/asmiati/5c2da22faeebe1434934aab8/ -and-opportunity-economy-indonesia-in-2019? Page $=$ semua pada 10 Agustus 2019 pada 9:00 WIB 18.03 WIB. 